\title{
Idiopathic Omental Bleeding Treated by Laparoscopic Partial Omentectomy: A Case Report and Review of the Literature
}

\author{
Shoryu Takayama ${ }^{1}$, Koshiro Harata ${ }^{2}$, Rei Mizuno ${ }^{3}$, Riki Ganeko ${ }^{3}$ \\ 1. Surgery, Nagoya Tokushukai General Hospital, Nagoya, JPN 2. Gastrointestinal Surgery, Nagoya City University East \\ Medical Center, Nagoya, JPN 3. Gastrointestinal Surgery, Uji Tokushukai Hospital, Kyoto, JPN
}

Corresponding author: Shoryu Takayama, gaoshanshenglong@gmail.com

\begin{abstract}
Omental bleeding is potentially life-threatening. There are many causes of omental bleeding including trauma, neoplasia, arterial aneurysm rupture, omental torsion, vasculitis, or segmental arterial mediolysis (SAM). Without remarkable pathological features, the diagnosis of idiopathic omental bleeding is made. Omental bleeding is relatively a rare disease, and there is no established treatment strategy.
\end{abstract}

A 53-year-old woman was brought to the ED for sudden onset abdominal pain. CT revealed hematoma in the omentum and was diagnosed as idiopathic omental bleeding accordingly. The patient underwent laparoscopic partial omentectomy and was discharged nine days after surgery. The pathological findings of the resected omentum were not remarkable, and the final diagnosis was made as idiopathic omental bleeding.

In some case reports of omental bleeding, interventional radiology (IVR) was chosen for hemostasis, but IVR cannot resect tissue of omentum so it is difficult to make a pathological diagnosis. The surgical approach of idiopathic omental bleeding is uncommon. However, the use of the laparoscopic approach hasn't been reported in the literature. Laparoscopic partial omentectomy can provide effective hemostasis. We report laparoscopic partial omentectomy surgical procedure and review of the literature.

Review began 06/02/2021 Review ended 06/09/2021 Published 06/21/2021

(c) Copyright 2021

Takayama et al. This is an open access article distributed under the terms of the Creative Commons Attribution License CC-BY 4.0., which permits unrestricted use, distribution, and reproduction in any medium, provided the original author and source are credited.
Categories: Cardiac/Thoracic/Vascular Surgery, Emergency Medicine, General Surgery

Keywords: idiopathic omental bleeding, laparoscopic surgery, intra-abdominal bleeding, omentectomy, ivr

\section{Introduction}

Omental bleeding results from trauma, neoplasia [1], arterial aneurysm rupture [2], omental torsion [3], vasculitis [4], or segmental arterial mediolysis (SAM) [5]. Without remarkable pathological features, the diagnosis of idiopathic omental bleeding is made [6]. Omental bleeding is potentially life-threatening, so it is necessary to provide effective hemostasis. Omental bleeding is a relatively rare disease, and there is no established treatment strategy. In recent years, interventional radiology (IVR) provided effective hemostasis in some cases of omental bleeding [7], but IVR cannot resect tissue of omentum so it is difficult to make a pathological evaluation. In some case reports, surgical treatment was chosen, but laparoscopic surgical treatment is not reported.

\section{Case Presentation}

A 53-year-old woman, who is a known case of rheumatoid arthritis, was brought to the ED complaining of sudden onset right upper quadrant pain one hour ago without any trauma history. Her medications include methotrexate and methylprednisolone. Her surgical history included appendicectomy 35 years ago and cesarean section 20 years ago. On physical examination, her blood pressure was 135/86 $\mathrm{mmHg}$ and pulse was $80 / \mathrm{min}$. There was tenderness in the right upper quadrant, and her abdomen was rigid. Laboratory studies showed a hemoglobin level of $11.8 \mathrm{~g} / \mathrm{dl}$, white blood cell count of $7700 / \mu \mathrm{l}$, platelet count of $24.2 \times 10^{4} \mu \mathrm{l}$, and other data were within normal range. Contrast-enhanced CT showed hemorrhagic ascites in the extrahepatic region and hematoma in the omentum and omental bursa with no extravasation (Figure 1). As a result, a preoperative diagnosis of omental bleeding was established. There was no evidence of active bleeding and her vital signs were stable, therefore we performed laparoscopic partial omentectomy. 


\section{Cureus}

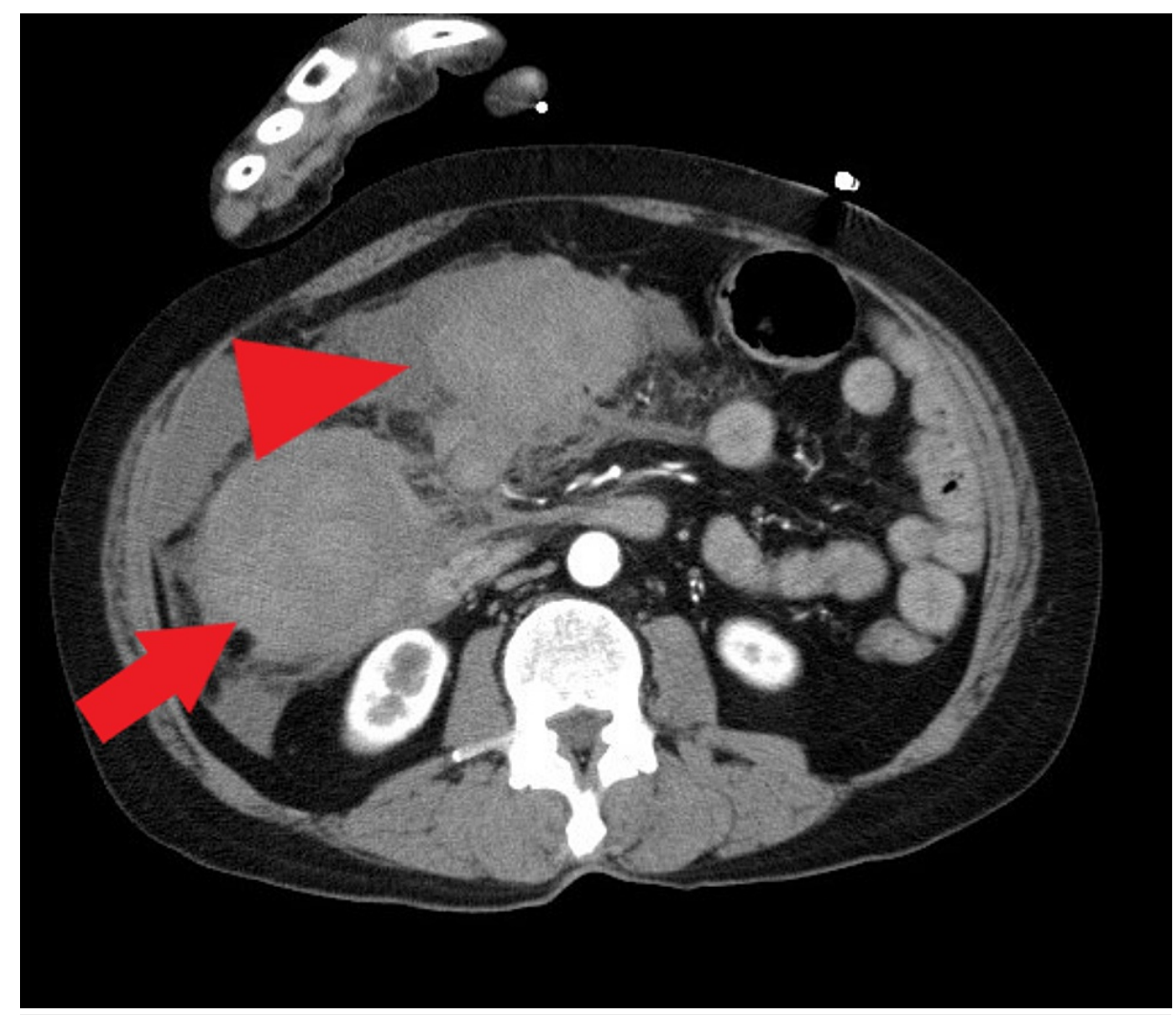

\section{FIGURE 1: Preoperative contrast CT.}

Contrast CT showed hemorrhage ascites in the extrahepatic region (arrow) and hematoma in the omentum and omental bursa (arrowhead).

First, the omentum was separated from the attachment to the transverse colon and the omental bursa was opened (Figure $2 A$ ). The omentum was cut to the right border of the omental bursa, taking care not to damage the mesentery of the transverse colon (Figure $2 B$ ). Next, the omentum was separated from the gastric wall (Figure 2C). Then the right gastroepiploic artery and vein (RGEA.V) were clipped and

dissected (Figure 2D). Omentum tissue was then dissected and the specimen was removed. Finally, 6.5-mm continuous suction drains were placed by the extrahepatic cavity, left subdiaphragmatic cavity, and Douglas fossa. Because there were no remarkable pathological findings in the removed omentum, the diagnosis of idiopathic omental bleeding was made. The postoperative course was very good, and the patient was discharged nine days after surgery. After three months, she came to the outpatient clinic and her laboratory studies were within normal range and ultrasonography showed no ascites and hematoma. 


\section{Cureus}

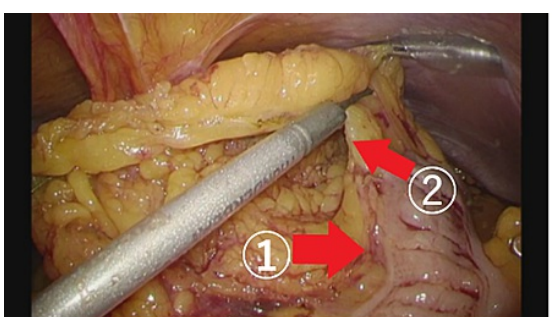

A

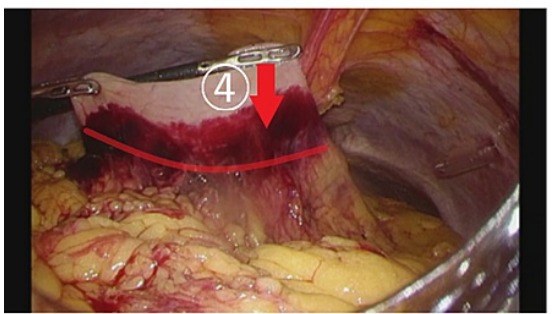

C

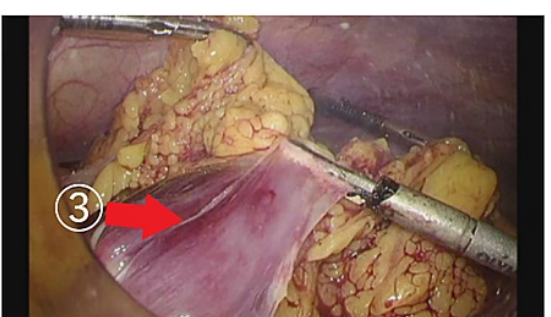

B

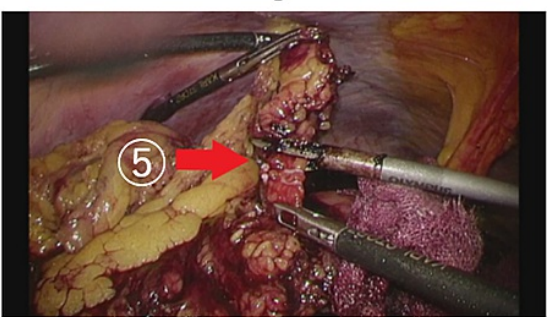

D

\section{FIGURE 2: Surgical procedure.}

[A] The omentum was separated from the attachment to the transverse colon (1) and the omental bursa (2) was opened. $[\mathrm{B}]$ The omentum was separated to the right border of the omental bursa taking care not to damage the mesentery of the transverse colon (3). [C] The omentum was separated from the gastric wall (4). [D] The right gastroepiploic artery and vein (RGEA.V) (5) were clipped and cut.

\section{Discussion}

Omental bleeding is a relatively rare disease, and there is no established treatment strategy. We searched for case reports about omental bleeding and found 25 cases (Table 1). Treatments were reported as transcatheter arterial embolization (TAE) or laparotomy. TAE can provide effective hemostasis when rapid hemostasis is required. However, there was a case in which partial omentectomy was performed for pathological evaluation after TAE [8]. Pathological evaluation is necessary because some omental bleedings result from neoplasia, arterial aneurysm rupture, omental torsion, vasculitis, and SAM. If omental bleeding is diagnosed preoperatively and patient status is stable, surgery may be a good choice because it can provide effective hemostasis and resect tissue of omentum simultaneously. All cases of omental bleeding treated by surgery were performed by laparotomy. These reported cases underwent either ligation or partial omentectomy. In this case report, we performed laparoscopic partial omentectomy. Although there is no report of laparoscopic partial omentectomy, this procedure can be performed for patients with stable preoperative vital signs and no extravasation like our case. For example, patients whose postoperative diagnosis was idiopathic omental bleeding or omental torsion (Table 1) might be suitable for a laparoscopic partial omentectomy approach, because their vital signs were stable.

\begin{tabular}{|c|c|c|c|c|c|c|c|c|c|}
\hline \multirow[t]{2}{*}{ Case } & \multirow[t]{2}{*}{ First author } & \multirow[t]{2}{*}{ Year } & \multirow[t]{2}{*}{ Age/Gender } & \multirow[t]{2}{*}{ Chief complaint } & \multirow{2}{*}{$\begin{array}{l}\text { Shock } \\
\text { vital }\end{array}$} & \multicolumn{2}{|c|}{ Examination } & \multirow{2}{*}{$\begin{array}{l}\text { Therapy/Surgical } \\
\text { technique }\end{array}$} & \multirow[t]{2}{*}{ Pathology } \\
\hline & & & & & & CT & IVR & & \\
\hline 1 & & 1950 & 49/M & Abdominal pain & & NA & - & Laparotomy & NR \\
\hline 2 & & 1951 & $52 / F$ & $\begin{array}{l}\text { Pain in the right lower quadrant of } \\
\text { the abdomen }\end{array}$ & & NA & - & Laparotomy & NR \\
\hline 3 & & 1949 & $51 / F$ & $\begin{array}{l}\text { Right upper abdominal pain, nausea, } \\
\text { and vomiting }\end{array}$ & & NA & - & Laparotomy & NR \\
\hline 4 & & 1951 & $27 / \mathrm{M}$ & $\begin{array}{l}\text { Discomfort in the right upper } \\
\text { quadrant of the abdomen }\end{array}$ & & NA & - & Laparotomy & NR \\
\hline 5 & & 1945 & $82 / \mathrm{M}$ & $\begin{array}{l}\text { Abdominal pain, vomiting, and } \\
\text { nausea }\end{array}$ & & NA & - & Laparotomy & NR \\
\hline 6 & & 1950 & $64 / \mathrm{M}$ & Abdominal pain & & NA & - & Laparotomy & NR \\
\hline 7 & Heritz DM et al. [5] & 1990 & 68/M & Abdominal pain & $\begin{array}{l}\text { Shock } \\
\text { vital }\end{array}$ & 0 & 0 & $\begin{array}{l}\text { Laparotomy partial } \\
\text { omentectomy }\end{array}$ & SAM \\
\hline & & & & & & & & Laparotomy partial & Wegen \\
\hline
\end{tabular}




\section{Cureus}

\begin{tabular}{|c|c|c|c|c|c|c|c|c|c|}
\hline 8 & Kroot EJ et al. [4] & 2003 & 70/M & Abdominal pain & & O & - & omentectomy & granulomatosis \\
\hline 9 & Jadav M et al. [2] & 2004 & $60 / \mathrm{M}$ & $\begin{array}{l}\text { Acute abdomen, nausea, vomiting, } \\
\text { and diarrhea }\end{array}$ & & 0 & - & Laparotomy & NA \\
\hline 10 & Finly DS et al. [9] & 2005 & $41 / \mathrm{M}$ & Abdominal pain & & $\mathrm{O}$ & - & $\begin{array}{l}\text { Laparotomy ligation of } \\
\text { the omental varix }\end{array}$ & NA \\
\hline 11 & Ohno T et al. [10] & 2005 & $27 / \mathrm{M}$ & Intermittent abdominal pain & & $\mathrm{O}$ & - & $\begin{array}{l}\text { Laparotomy partial } \\
\text { omentectomy }\end{array}$ & NR \\
\hline 12 & Nagaba Y et al. [11] & 2005 & 64/M & Acute abdomen & $\begin{array}{l}\text { Shock } \\
\text { vital }\end{array}$ & $\mathrm{O}$ & 0 & TAE & - \\
\hline 13 & $\begin{array}{l}\text { Matsumoto T et al. } \\
{[8]}\end{array}$ & 2010 & $25 / \mathrm{M}$ & Abdominal pain & & $\mathrm{O}$ & 0 & $\begin{array}{l}\text { TAE } \rightarrow \text { Laparotomy } \\
\text { partial omentectomy }\end{array}$ & NR \\
\hline 14 & $\begin{array}{l}\text { Henry D and } \\
\text { Satgunam S [6] }\end{array}$ & 2012 & $24 / F$ & Malaise, myalgias, and fatigue & & $\mathrm{O}$ & - & $\begin{array}{l}\text { Laparotomy-only } \\
\text { ligation }\end{array}$ & - \\
\hline 15 & $\begin{array}{l}\text { Takahashi M et al. } \\
\text { [7] }\end{array}$ & 2012 & $27 / M$ & Abdominal pain, feeling faint & & 0 & 0 & TAE & - \\
\hline 16 & Cheng VE et al. [12] & 2014 & 68/M & $\begin{array}{l}\text { Acute hypotension, severe left } \\
\text { abdominal pain }\end{array}$ & $\begin{array}{l}\text { Shock } \\
\text { vital }\end{array}$ & $\mathrm{O}$ & - & Laparotomy & NA \\
\hline 17 & $\begin{array}{l}\text { Aumann V et al. } \\
\text { [13] }\end{array}$ & 2016 & 20/M & NA & & $\mathrm{O}$ & - & Laparotomy & NR \\
\hline 18 & Kimura J et al. [14] & 2016 & 29/M & Abdominal pain & & $\mathrm{O}$ & - & $\begin{array}{l}\text { Laparotomy partial } \\
\text { omentectomy }\end{array}$ & NR \\
\hline 19 & Lyu YX et al. [15] & 2018 & $58 / \mathrm{M}$ & Left upper quadrant pain & & $\mathrm{O}$ & - & $\begin{array}{l}\text { Laparotomy partial } \\
\text { omentectomy }\end{array}$ & NR \\
\hline 20 & $\begin{array}{l}\text { Mahmoudi A et al. } \\
\text { [1] }\end{array}$ & 2020 & 3/M $>2>>2$ & Abdominal distention & & 0 & - & $\begin{array}{l}\text { Laparotomy partial } \\
\text { omentectomy }\end{array}$ & Lymphangioma \\
\hline 21 & Nishiyama T et al. & 2020 & $55 / \mathrm{M}$ & Acute abdomen & & 0 & 0 & TAE & - \\
\hline 22 & [16] & & $60 / \mathrm{M}$ & Acute abdomen & & 0 & 0 & TAE & - \\
\hline 23 & & & $60 / \mathrm{M}$ & Feeling faint & $\begin{array}{l}\text { Shock } \\
\text { vital }\end{array}$ & $\mathrm{O}$ & O & TAE & - \\
\hline 24 & $\begin{array}{l}\text { Moriarty HK et al. } \\
\text { [17] }\end{array}$ & 2 & $37 / F$ & Abdominal pain, feeling faint & $\begin{array}{l}\text { Shock } \\
\text { vital }\end{array}$ & $\mathrm{O}$ & 0 & TAE & - \\
\hline 25 & & & 69/F & Abdominal pain & & 0 & 0 & TAE & - \\
\hline
\end{tabular}

\section{TABLE 1: Omental bleeding case reports.}

NA: Not available; NR: Not remarkable; IVR: Interventional radiology; SAM: Segmental arterial mediolysis; TAE: Transcatheter arterial embolization.

\section{Conclusions}

Idiopathic omental bleeding is a relatively rare disease, and laparoscopic surgical approach was not reported in the literature. Laparoscopic partial omentectomy can provide effective hemostasis and pathological evaluation. When a patient is stable and without extravasation, laparoscopic partial omentectomy may be the first choice to treat.

\section{Additional Information \\ Disclosures}

Human subjects: Consent was obtained or waived by all participants in this study. Conflicts of interest: In compliance with the ICMJE uniform disclosure form, all authors declare the following: Payment/services info: All authors have declared that no financial support was received from any organization for the submitted work. Financial relationships: All authors have declared that they have no financial relationships at present or within the previous three years with any organizations that might have an interest in the submitted work. Other relationships: All authors have declared that there are no other 


\section{References}

1. Mahmoudi A, Rami M, Khattala K, El Madi A, Bouabdallah Y: Huge omental lymphangioma with haemorrhage in children: case report. Pan Afr Med J. 2020, 35:20. 10.11604/pamj.2020.35.20.8585

2. Jadav M, Ducheine Y, Brief D, Carter L, McWhite T, Hardy J: Abdominal apoplexy: a case study of the spontaneous rupture of the gastroepiploic artery. Curr Surg. 2004, 61:370-372. 10.1016/j.cursur.2004.01.005

3. Leitner MJ, Jordan CG, Spinner MH, Reese EC: Torsion, infarction and, hemorrhage of the omentum as a cause of acute abdominal distress. Ann Surg. 1952, 135:103-110. 10.1097/00000658-195201000-00014

4. Kroot EJ, Mak CL, Boelhouwer RU, Middelkoop MP, Dees A: Involvement of the omentum in Wegener's granulomatosis. Ann Rheum Dis. 2003, 62:1238-1239. 10.1136/ard.2003.012310

5. Heritz DM, Butany J, Johnston KW, Sniderman KW: Intraabdominal hemorrhage as a result of segmental mediolytic arteritis of an omental artery: case report. J Vasc Surg. 1990, 12:561-565. 10.1016/07415214(90)90011-X

6. Henry D, Satgunam S: Idiopathic omental bleeding. J Surg Case Rep. 2012, 2012:2. 10.1093/jscr/2012.9.2

7. Takahashi M, Matsuoka Y, Yasutake T, Abe H, Sugiyama K, Oyama K: Spontaneous rupture of the omental artery treated by transcatheter arterial embolization. Case Rep Radiol. 2012, 2012:273027. $10.1155 / 2012 / 273027$

8. Matsumoto $\mathrm{T}$, Yamagami $\mathrm{T}$, Morishita $\mathrm{H}$, et al.: Transcatheter arterial embolization for spontaneous rupture of the omental artery. Cardiovasc Intervent Radiol. 2011, 34:142-145. 10.1007/s00270-010-9956-1

9. Finley DS, Lugo B, Ridgway J, Teng W, Imagawa DK: Fatal variceal rupture after sildenafil use: report of a case. Curr Surg. 2005, 62:55-56. 10.1016/j.cursur.2004.06.019

10. Ohno T, Ogata K, Aiba S, et al.: Idiopathic omental bleeding: report of a case . Surg Today. 2005, 35:493-495. 10.1007/s00595-004-2960-9

11. Nagaba Y, Nishimaki H, Ichinoe M, et al.: Spontaneous rupture of a left gastroepiploic artery aneurysm in a patient with autosomal-dominant polycystic kidney disease. Clin Nephrol. 2005, 63:163-166. 10.5414/cnp63163

12. Cheng VE, Oppermen A, Natarajan D, Haikerwal D, Pereira J: Spontaneous omental bleeding in the setting of dual anti-platelet therapy with ticagrelor. Heart Lung Circ. 2014, 23:e115-e117. 10.1016/j.hlc.2013.11.002

13. Aumann V, Chiapponi C, Meyer F, Wybranski C, Bruns CJ, Jannasch O: Spontaneous omental bleeding in a 20-year old patient with hemophilia A. A rare cause for emergency laparotomy. Hamostaseologie. 2016, 36:S22-S24.

14. Kimura J, Okumura K, Katagiri H, Lefor AK, Mizokami K, Kubota T: Idiopathic omental hemorrhage: a case report and review of the literature. Int J Surg Case Rep. 2016, 28:214-218. 10.1016/j.ijscr.2016.10.003

15. Lyu Y-X, Cheng Y-X, Li T: Spontaneous omental bleeding: a case report and literature review . BMC Surg. 2018, 18:33. 10.1186/s12893-018-0364-9

16. Nishiyama T, Yamada D, Oba K, Kurihara Y: Left omental artery bleeding in two patients with segmental arterial mediolysis successfully isolated with coil embolization. CVIR Endovasc. 2020, 3:36. 10.1186/s42155020-00127-0

17. Moriarty HK, Martin K, Koukounaras J, Goh GS, Clements W: Omental apoplexy: unravelling the mystery. J Med Imaging Radiat Oncol. 2020, 64:319-325. 10.1111/1754-9485.13024 